\title{
AN ANALYSIS OF ASPECTS OF THE PROPOSED REFORM OF THE FINANCIAL CONSUMER COMPLAINT RESOLUTION MECHANISMS IN THE SOUTH AFRICAN BANKING SECTOR
}

\author{
Michel M Koekemoer \\ BCom LLB LLM LLD \\ Senior Lecturer, Department of Mercantile Law \\ University of South Africa
}

\section{SUMMARY}

One objective of the revised South African market conduct regulatory framework for the financial sector is to introduce an effective dispute resolution framework. The Financial Sector Regulation Act, and the Act to follow the Draft Conduct of Financial Institutions Bill, potentially address some of the deficiencies associated with the old dispute resolution framework. This article makes a distinction between the old and new regulatory provisions concerning internal dispute resolution and external dispute resolution structures in the banking sector. This research highlights the changes involved in the new regulatory framework and identifies which aspects of the amended regulatory framework aim to address a particular issue associated with the old dispute resolution framework. It is not argued whether this legislation will achieve the fair treatment and protection of financial customers in the banking sector, as only time will tell. However, it is acknowledged that the new structure will improve consistency and efficacy in this dispute resolution structure.

\section{$1 \quad$ INTRODUCTION}

A financial customer must be able to lodge a complaint concerning a bank with an effective complaint resolution forum. This article makes a distinction between the old and new regulatory provisions concerning the framework for internal and external dispute resolution in the banking sector. Alternative dispute resolution (ADR) mechanisms, typically ombud schemes, serve as the external complaint resolution forum operational in the banking sector.

One of the objectives of the revised South African market conduct regulatory framework for the financial sector is to introduce effective dispute 
resolution processes. ${ }^{1}$ This article makes a novel contribution in identifying how the provisions of the Financial Sector Regulation Act (FSR Act) $)^{2}$ and the Draft Conduct of Financial Institutions Bill (COFI Bill) ${ }^{3}$ could correct certain issues associated with the previous dispute resolution framework. The new provisions introduced by the FSR Act that impact on the operation of ombud schemes in the financial sector are discussed under heading 4 below. These provisions relate mostly to the new ombud scheme oversight bodies, namely, the Ombud Council (OC) and the Financial Services Tribunal (FST). The COFI Bill aims to improve the internal complaint procedures of financial institutions. Accordingly, under heading 5 below, this contribution examines the broad framework of, and aspects concerning, internal dispute resolution mentioned in the COFI Bill, and to some degree, the FSR Act. The exclusive focus of this article is on the traditional banking sector, which sector forms part of the financial sector.

\section{A SYNOPSIS OF THE REGULATORY INSTRUMENTS DETERMINING THE DISPUTE RESOLUTION FRAMEWORK}

The legislation determining the structure of the dispute resolution framework includes: (1) the National Credit Act (NCA), ${ }^{4}$ regarding credit agreement disputes; (2) the Financial Advisory and Intermediaries Services Act (FAIS Act), ${ }^{5}$ which, among other matters, regulates the conduct of the Ombud for Financial Services Providers (FAIS Ombud), and prescribes how financial institutions should resolve consumer complaints to which the FAIS Act applies; and (3) the Financial Services Ombud Schemes (FSOS) Act (repealed), ${ }^{6}$ which provided the operational framework predominantly for voluntary ombud schemes, but also in some respects for statutory ombud schemes.

Schedule 4 of the FSR Act repealed the FSOS Act with effect from 31 May 2021. Moreover, Schedule 4 also amends sections of the FAIS Act with most amendments being effective from 1 April 2018, excluding those provisions directly related to complaint resolution by the Ombud and the introduction of the Ombud Council, which will be effective from 1 April 2022. Chapter 14 of the FSR Act concerns the regulation of ombud schemes and comes into operation to coincide with the repeal of the whole of the FSOS

National Treasury "Explanatory Policy Paper Accompanying the Conduct of Financial Institutions Bill" (2018) http://pmg-assets.s3-website-eu-west-1.amazonaws.com/ 181211CoFI_Bill_policy_paper.pdf (accessed 2020-04-22) 8.

29 of 2017 (FSR Act).

3 The first draft of the COFI Bill was published for comment during 2018. See https://pmg.org.za/call-for-comment/784/ (accessed 2020-05-22). The second draft of the COFI Bill was published in September 2020. See http://www.treasury.gov.za/legislation/ GovernmentNotices/43741_29-09_NatTreasury.pdf (accessed 2021-05-13).

34 of 2005 (NCA).

37 of 2002 (FAIS Act).

37 of 2004 (FSOS Act). The whole Act was repealed with effect from 31 May 2021. 
Act and parts of the FAIS Act. Moreover, the COFI Bill ${ }^{7}$ advises how financial institutions (including banks) should treat their clients, in line with the "Treating Customers Fairly" principles. ${ }^{8}$ Chapter 7 of the COFI Bill prescribes specific requirements for the complaint management process of financial institutions, and the aim is to introduce uniformity into how financial institutions deal with complaints.

Examples of other regulatory instruments include codes of conduct, and the most prevalent are mentioned. First, the Code of Good Banking Practice (Banking Code) is a voluntary code of conduct. The current status of the Banking Code is regarded as "universally and uniformly observed within the banking industry". ${ }^{9}$ Du Toit makes this comment after considering that most banks apply the Banking Code in their client dealings. The second most prevalent code, a statutory code of conduct, is the General Code of Conduct for Authorised Financial Services Providers and Representatives (Financial Services Providers Code). ${ }^{10}$ In particular, Part XI, deals with complaint resolution by a financial services provider, where a provider could include a bank. ${ }^{11}$

\section{EXISTING EXTERNAL DISPUTE RESOLUTION MECHANISMS}

\section{Introduction}

There are two broad categories of ombud scheme operating in the financial sector. ${ }^{12}$ The first category, the statutory ombud scheme, derives its mandate from specific legislation, and/or a related instrument as discussed

7 National Treasury http://pmg-assets.s3-website-eu-west1.amazonaws.com/ 181211CoFI_Bill_policy_paper.pdf.

$8 \quad$ FSB "Treating Customers Fairly: Complaints Management Discussion Document" (October 2014) https://www.fsca.co.za/Regulatory\%20Frameworks/Documents\%20for\%20 Consultation/TCF\%20Complaints\%20Management\%20Discussion\%20Document.pdf (accessed 2018-04.28) 1.

9 Du Toit "Reflections on the South African Code of Banking Practice" 2014 TSAR 570. See a general discussion of the Banking Code in Uzokwe and Van Heerden "Consumer Protection in the Banking Industry: A Comparison of the South African and Nigerian Codes of Banking Practice" 201881 THRHR 631-649.

10 A copy is available from https://faisombud.co.za/wp-content/uploads/2018/06/GeneralCode-of-Conduct-for-Authorised-Financial-Services-Providers-and-Representatives.pdf (accessed: 2020-05-07).

11 See Van Zyl "Codes of Conduct for the Financial Services Industry" 200617 Stell LR 333-347 for a general discussion of the voluntary codes that exist in the financial services industry. For another example of an industry code, see the Association for Savings and Investment in South Africa "Treating Customers Fairly (TCF): Best Practice Guidelines for ASISA Members" (2011) https://www.asisa.org.za/wp-content/uploads/2017/05/tcf-bestpractices-guideline-for-asisa-members-nov-2011.pdf (accessed 2020-05-04).

12 There is potentially a third category, referred to as the "back-stop" ombud, which takes on the role where a matter does not directly fall in the jurisdiction of any ombud. See National Treasury "A Known and Trusted Ombud System for All" (September 2017) http://www.treasury.gov.za/twinpeaks/Final\%20Twin\%20Peaks\%20Policy\%20Doc_A\%20kn own\%20and\%20trusted\%20ombuds\%20system\%20for\%20all_September2017.pdf (accessed 2019-02-05) 6. 
above. ${ }^{13}$ Examples of statutory ombud schemes in the financial sector include: (1) the FAIS Ombud regulated by the provisions of the FAIS Act and the Rules on Proceedings of the Office of the Ombud for Financial Services Providers (FAIS Ombud Rules), ${ }^{14}$ and the Financial Services Providers Code; ${ }^{15}$ (2) the Pension Funds Adjudicator regulated by the Pension Funds Act: ${ }^{16}$ and (3) the Registrar of the Council for Medical Aid Schemes, regulated by the Medical Schemes Act. ${ }^{17}$

The second category, the voluntary ombud scheme, derives its mandate from either: (1) the codes of conduct regulating different industries; and/or (2) the terms of reference for the respective ombud scheme, drafted considering the provisions of the now-repealed FSOS Act, ${ }^{18}$ and agreed to contractually among members. ${ }^{19}$ Examples of voluntary ombud schemes in the financial sector include the Ombudsman for Long-Term Insurance, the Ombudsman for Short-Term Insurance, the Johannesburg Stock Exchange Ombud and the Ombudsman for Banking Services (OBS).

The National Credit Regulator $(\mathrm{NCR})^{20}$ and the National Consumer Tribunal (NCT) are the primary dispute resolution forums for disputes concerning credit agreements in the banking sector. ${ }^{21}$ According to section 134 of the NCA, a consumer may also approach an ombud with jurisdiction, ${ }^{22}$ a consumer court or an ADR agent concerning a dispute related to a credit agreement. ${ }^{23}$ Consequently, the consumer can also refer a dispute relating to a credit agreement to the OBS, depending on whether the OBS mandate allows the OBS to adjudicate on the matter. The remainder of the discussion is limited to the primary ombud schemes operating in the traditional banking sector, namely, the OBS and the FAIS Ombud.

13 S 1 of the FSR Act defines a statutory ombud as either the Pension Funds Adjudicator, the FAIS Ombud or another ombud declared by a financial sector law as a statutory ombud scheme.

14 Issued by the Financial Services Board. See GN 81 of 2003 in GG 25299 of 2003-08-08.

15 See https://faisombud.co.za/about-us/mandate/ (accessed 2020-04-28).

1624 of 1956.

17131 of 1998

18 Woker "Evaluating the Role of the National Consumer Commission in Ensuring That Consumers Have Access to Redress" 201729 SA Merc LJ 4.

19 National Treasury http://www.treasury.gov.za/twinpeaks/Final\%20Twin\%20Peaks\%20Policy \%20Doc_A\%20known\%20and\%20trusted\%20ombuds\%20system\%20for\%20all_Septembe r2017.pdf 6 .

20 Regulation 50 of the National Credit Regulations sets out the process for initiating a complaint to the NCR. The NCR is an example of a sector regulator that handles consumer complaints.

21 The jurisdiction of the Tribunal on credit matters is contained in s 26(1) of the NCA. The National Credit Amendment Act 19 of 2014 extended the Tribunal's mandate on creditrelated disputes and the Tribunal also entertains applications on reckless credit.

22 The definition of "ombud with jurisdiction" in the NCA was amended to include reference to the definition contained in the FSR Act (according to Schedule 4 of the FSR Act).

23 The discussion concerning the NCR and NCT is not taken further, apart from acknowledging that this is the structure prescribed by the NCA for the resolution of disputes concerning credit agreements subject to the NCA. 


\section{The primary ombud schemes in the banking sector}

The OBS, established in terms of section 11 of the FSOS Act, is an "industry ombud scheme" in terms of section 1 the FSR Act. In turn, the FAIS Ombud, a statutory ombud under the FSR Act, was established in terms of section 20 of the FAIS Act. The OBS must consider the following documents and/or principles when adjudicating a complaint: (1) the OBS Terms of Reference and operational procedures;24 (2) the provisions of the Banking Code; (3) relevant case law and legislation; (4) best practice internationally; and (5) the principles of equity or fairness. ${ }^{25}$ In contrast, the mandate of the FAIS Ombud comes from the FAIS Act and the Rules promulgated in terms of this Act. ${ }^{26}$

The OBS only entertains complaints concerning a bank that is a member of the Banking Association of South Africa (BASA) where the claim amount is R2 million or less, which threshold is higher than that of the FAIS Ombud where the monetary value of a claim may not exceed R800 000. ${ }^{27}$ In contrast, the FAIS Ombud can hear complaints against all financial services providers where: (1) the provider contravened the provisions of the FAIS Act and the customer suffered or is likely to have suffered financial prejudice or damage; (2) the provider acted wilfully or negligently when providing a financial service and the customer suffered or is likely to have suffered a financial prejudice or damage as a result; or (3) the provider treated the customer unfairly. ${ }^{28}$

The OBS will not entertain a claim that has prescribed or where the complaint originates from a company with a business turnover of R10 million or more. Moreover, the OBS does not assist with complaints related to the following: (1) a bank's decision concerning lending or credit, interest rates or bank charges grounded in sound commercial reasoning, unless maladministration is clearly evident; ${ }^{29}$ (2) a matter that can be more appropriately handled by a court of law or another dispute forum; or (3) a matter under litigation. ${ }^{30}$ Additionally, the OBS cannot consider a complaint or dispute that would fall within the exclusive jurisdiction of any statutory ombud. ${ }^{31}$ In respect of both the OBS and the FAIS Ombud, the complainant

\footnotetext{
24 Ombudsman for Banking Services "Terms of Reference" (February 2018) https://www.obssa.co.za/wp-content/uploads/2018/02/Terms-of-Reference-Final-February2018.pdf (accessed 2020-04-03).

25 See https://www.obssa.co.za/about/wherewecanhelp/ (accessed 2020-04-03).

26 FAIS Ombud "Circular 2 of 2018: Financial Services Ombud Scheme Act 37 of 2004 FSOS Act" (October 2018) https://faisombud.co.za/wp-content/uploads/2018/10/Circular2 2018-1.pdf.

27 See https://faisombud.co.za/about-us/mandate/ (accessed 2020-04-28).

28 Ibid.

29 This is an example of the consequences of banks being able to determine the jurisdiction of this ombud scheme. See National Treasury http://www.treasury.gov.za/twinpeaks/ Final\%20Twin\%20Peaks\%20Policy\%20Doc_A\%20known\%20and\%20trusted\%20ombuds \%20system\%20for\%20all_September2017.pdf 10.

30 lbid.

31 OBS Terms of Reference par 3.2(c)(i).
} 
must attempt to resolve the dispute with the financial institution before approaching an ombud scheme.

The OBS may make a recommendation or determination of compensation to the maximum of R2 million, which can include amounts for "distress and inconvenience" not exceeding R50 000.32 The OBS recommendation can be made an order of court, but the determination does not automatically carry the same weight as a court order, unlike a FAIS Ombud determination. ${ }^{33}$ Also, the OBS may publish the name of those banks that do not comply with a recommendation. ${ }^{34}$

The number of complaints received during a reporting period for both the FAIS Ombud and the OBS remains low when contrasted against the number of South African financial customers. ${ }^{35}$ The FAIS Ombud received 9323 complaints during the 2018/2019 financial year, settling 1209 in favour of the complainant. ${ }^{36}$ The OBS figures for the 2019 reporting period are more detailed. The OBS received: 326 walk-ins, 4709 referrals for adjudication, and 26257 calls in the call centre. ${ }^{37}$ From these complaints, the OBS opened 6333 cases. $^{38}$

Indeed, private sector initiatives may be more efficient compared to a statutory arrangement, but proper research is required before amending the existing structure. ${ }^{39}$ Different models of how to change the current structure of ombud schemes in the financial sector have been recommended. 40 However, the final determination on the new structure remains uncertain. Until a proposal is accepted, the existing ombud schemes remain operational.

32 OBS Terms of Reference paras 1.3(a) and 3.2(a)(ii)

33 See https://faisombud.co.za/about-us/mandate/ (accessed 2020-04-28).

34 Uzokwe and Van Heerden 2018 THRHR 638. See also OBS "2018 Annual Report" (May 2019) https://www.obssa.co.za/wp-content/uploads/2019/05/J25144_OBSSA_Annual_ Report_2018_FA_Spreads.pdf (accessed 2020-05-08) 15.

35 The number of clients per bank according to the Consumer Satisfaction Survey of 2019 include: 11.4 million for Capitec, 8.2 million for FirstRand Ltd, 8.1 million for Standard Bank Ltd, and 7.9 million for Nedbank Ltd. See https://businesstech.co.za/news/banking/ 339319/battle-of-the-banks-south-africas-big-5-banks-compared/ (accessed 2020-05-11).

36 FAIS Ombud Annual Report 2018/2019 at 19 available from https://faisombud.co.za/wp content/uploads/2019/12/FAIS_Ombud_Annual_Report_2018-2019.pdf (accessed 2020-0507). The 2019/2020 annual report was not available at time of publication.

37 OBS https://www.obssa.co.za/wp-content/uploads/2020/05/J26691_OBSSA_AnnualReport_FA-Spreads.pdf 19.

38 Ibid.

39 Melville "Has Ombudsmania Reached South Africa? The Burgeoning Role of Ombudsment in Commercial Dispute Resolution" 201022 SA Merc LJ 65.

40 National Treasury http://www.treasury.gov.za/twinpeaks/Final\%20Twin\%20Peaks\%20 Policy\%20Doc_A\%20known\%20and\%20trusted\%20ombuds\%20system\%20for\%20all_Sep tember2017.pdf 27-36. 


\section{Oversight and funding of ombud schemes until sections of the FSR Act become operational}

The FSOS Council was responsible for the oversight of statutory and voluntary ombud schemes. However, the FAIS Ombud also reported to the Financial Services Board (FSB) concerning its overall functioning, and the FSB could also set rules concerning complaints and investigations procedures, which the FAIS Ombud would have to implement. ${ }^{41}$

In terms of section 8 of the FSOS Act, the FSOS Council was responsible for considering, and then granting or refusing, an application for the registration of an ombud scheme. In addition, the FSOS Council had to ensure sufficient coordination and co-operation between activities of the voluntary and statutory ombud schemes. Likewise, the FSOS Council was obligated to "develop and promote best practices" for a recommended complaint resolution procedure after consulting with a specific ombud, keeping in mind that these standards specifically apply to that ombud. It is entirely possible that the requirements and standards between ombud schemes could be different. Then, while performing its functions, the Council had to "ensure that the independence and impartiality of an ombud" were not affected. ${ }^{42}$ The FSOS Council had a consumer education responsibility, albeit phrased in a general manner, as the Council could issue guidelines to inform consumers of the jurisdiction and submission procedures of the different ombud schemes. ${ }^{43}$

Government (more specifically the FSB, as it then was) funded the operation of a statutory ombud. ${ }^{44}$ In contrast, voluntary ombud schemes are funded through subscription levies on members. ${ }^{45}$ It is a possible impediment to the independence of a voluntary ombud scheme that those members who fund the operation of the ombud scheme are the same members complained about.

\section{ASPECTS OF THE FSR ACT APPLICABLE TO} THE REGULATION OF CONSUMER DISPUTES

\section{Introduction to the FSR Act and the regulation of dispute resolution}

The FSR Act is the first piece of legislation introduced to give effect to the Twin Peaks model of regulation for the South African financial sector. ${ }^{46}$ The

41 The FSB was replaced by the Financial Sector Conduct Authority (FSCA) in terms of the FSR Act.

$42 \mathrm{~S} 8(1)(e)$ of the FSOS Act.

$43 \mathrm{~S} 8(2)(a)$ of the FSOS Act.

44 The FSCA is now responsible to fund the FAIS Ombud.

45 National Treasury http://www.treasury.gov.za/twinpeaks/Final\%20Twin\%20Peaks\%20 Policy\%20Doc_A\%20known\%20and\%20trusted\%20mbuds\%20system\%20for\%20all_Sep tember2017.pdf 6.

46 Uzokwe and Van Heerden 2018 THRHR note 13. 
second piece of legislation will be the Act enacted after the COFI Bill. The "Treating Customers Fairly" (TCF) principles forms an integral part of the above Twin Peaks model. ${ }^{47}$ According to TCF Outcome 6, customers should not face unreasonable post-sale barriers imposed by financial institutions when they change products or switch between providers, or when these customers want to submit a claim or lay a complaint against a financial institution. Linked to this TCF outcome, is the FSR Act objective to ensure the fair treatment and protection of financial customers. ${ }^{48} \mathrm{It}$ is submitted that providing a consumer with the opportunity to resolve a complaint against a financial institution fairly and effectively contributes to the fair treatment and protection of financial consumers. However, the "fair treatment and protection of financial consumers" is achieved when the fundamental principles of access, effectiveness, independence, transparency and fairness are fulfilled. ${ }^{49}$ Thus, to determine whether consumers are protected and treated fairly, content must be given to these principles to measure whether financial institutions (internal complaints resolution) and ombud schemes (external complaint resolution) resolve complaints in line with these fundamental principles. Also, both financial institutions and ombud schemes should comply with the same fundamental principles. Still, there may be a deviation between the extent to which the institution or scheme complies with a fundamental principle, in line with the principle-based approach, ${ }^{50}$ and such deviation must be considered when the regulatory authority determines whether a financial institution is compliant.

The internal dispute resolution mechanisms of financial institutions, as discussed in 53 below, are to be regulated by the Financial Sector Conduct Authority (FSCA). ${ }^{51}$ The external dispute resolution mechanisms will mostly be regulated by the OC and the FST under the new regulatory framework. ${ }^{52}$

\section{The Ombud Council}

The OC, replacing the FSOS Council, is established as a juristic person, and a national public entity for the purposes of the Public Finance Management Act ${ }^{53}$ according to section 175 of the FSR Act. The OC is to function as a

47 FSB https://www.fsca.co.za/Regulatory\%20Frameworks/Documents\%20for\%20 Consultation/TCF\%20Complaints\%20Management\%20Discussion\%20Document.pdf 1 .

$48 \quad \mathrm{~S} 7(1)(c)$ of the FSR Act.

49 These fundamental principles form part of the objective of the OC in terms of $s 176$ of the FSR Act.

50 Principle-based regulation means that the focus of a financial institution would be to achieve a specific outcome, but to a lesser extent, apply rule-based measures as well. See National Treasury http://pmg-assets.s3-website-eu-west1.amazonaws.com/181211CoFI_Bill_ policy_paper.pdf 11 .

51 The FSR Act established two new regulators, namely the Prudential Authority (PA) responsible for prudential regulation, and the FSCA responsible for market conduct regulation.

52 GenN 169 in GG 41549 of 2018-03-29, as amended by GN 1019 in GG 41947 of 2018-0928, as amended by GenN 142 in GG 42314 of 2019-03-18, as corrected by GN 657 in GG 42454 of 2019-05-10 and amended by GN 1130 in GG 42677 of 2019-08-30 and by GenN 356 in GG 43131 of 2020-03-24.

$53 \quad 1$ of 1999 . 
full-time statutory body, different from the FSOS Council, the latter having been managed by part-time staff. According to section 176 of the FSR Act, it is the objective of the OC to ensure that consumers have access and can use complaint processes that are "affordable, effective, independent and fair".

Section 177 sets out the functions of the OC, which, if achieved, will enable the $\mathrm{OC}$ to meet the above objective. First, the OC must recognise industry ombud schemes as schemes to which the FSR Act applies. The OC must then promote cooperation and coordination between different ombud schemes in the financial sector. In addition, the OC aims to protect the impartiality and independence of ombud schemes. Moreover, the OC must promote the public's awareness of ombud schemes. Then, as access is also an important principle, the OC must implement measures to provide consumers with access to the appropriate ombud schemes. The idea is for the $\mathrm{OC}$ to establish and operate centres that will direct financial consumers to the correct ombud scheme to hear complaints. ${ }^{54}$ Furthermore, the OC is responsible for publicising information concerning ombud schemes, which includes informing consumers of the kind of complaints different schemes may entertain. Moreover, when there is an overlap in the jurisdiction of the different ombud schemes, the $O C$ must resolve the overlap issue and decide which scheme should hear a complaint. Furthermore, the OC has a general monitoring function, monitoring whether ombud schemes comply with financial sector laws. The concluding function is that the OC should support financial inclusion in the financial sector.

The OC may issue two types of regulatory instrument to fulfil its functions and objective. The first type are the $\mathrm{OC}$ rules, which have a preventative purpose. In terms of section 201(1), the purpose of the OC rules is to achieve the OC's objective. Thus, the general purpose behind the OC rules is to ensure that consumers have access to affordable, effective, independent and fair ADR processes. Practically, ombud schemes will need to adopt the provisions of the OC rules as part of their terms of reference. The OC can also issue directives that require an ombud or ombud scheme to take steps to avoid contravening a financial sector law insofar as it relates to ombud schemes. ${ }^{55}$ According to section 204, the OC may commence proceedings against an ombud scheme in the High Court to ensure that the scheme complies with financial sector law. A contravention arguably also includes a contravention of the OC rules. Furthermore, according to section 206 of the FSR Act, the OC can impose administrative penalties on an ombud scheme, the ombud or the governing body of an ombud.

It appears as if the $O C$ is to be the link between the ombud schemes and the financial sector regulators, as well as the direct link to the Minister. The OC must inform the financial sector regulators which conduct of financial institutions is giving rise to complaints. ${ }^{56}$ Where there appears to be a trend,

54 See s 209 of the FSR Act, and the Financial Sector Conduct Authority "Twin Peaks Newsletter Issue 4: Establishing New Entities" https://www.fsca.co.za/TPNL/4/fsb4/ regulations.html (accessed 2020-03-27).

55 S 202(1) of the FSR Act.

$56 \mathrm{~S} 184(d)$ and $(e)$ of the FSR Act. 
a relevant regulator will be able to implement measures to regulate the general conduct of financial institutions.

Section 214 of the FSR Act requires the OC to approve an ombud scheme's initial governing rules and/or any subsequent amendments thereto (for example, in the case of the existing OBS and the FAIS Ombud). The criterion for approval is that the ombud scheme rules must assist the ombud scheme to achieve the FSR Act objectives. Furthermore, according to section 215 , where a financial institution is a member of an industry ombud scheme, the scheme rules are automatically incorporated into the bankclient contract concluded between the financial institution and the customer.

Section 217(1) requires ombud schemes to report annually to the OC concerning their operations. The voluntary ombud schemes and statutory ombud schemes must report to the same body (the OC), creating a standard reporting format applicable to all ombud schemes. Moreover, the $\mathrm{OC}$ is in a position to provide coordinated feedback on the ombud schemes to other financial sector regulators. Moreover, the FSCA may at any time request, either the OC, the statutory ombud scheme or a recognised industry ombud scheme to deliver a report either on the operation of the ombud scheme or regarding trends and implications of those trends of conduct of financial institutions. It is submitted that the value of the report to the FSCA is in the the identification of systematic complaints with a view to enhancing the control of the financial industry. The need for standardisation of the collection of data has been mentioned as a potential issue of concern in the financial sector. ${ }^{57}$ Thus, a previously raised issue, the lack of feedback to regulators, may be resolved. ${ }^{58}$

\section{Financial Services Tribunal}

The FST, established under section 219 of the FSR Act, for the judicial review of decisions of the financial sector regulators and the OC. According to section 219 of the FSR Act, the FST's function is to reconsider decisions (and omissions to take decisions) by a financial sector regulator, an authorised financial services provider (e.g., a bank), a statutory ombud (not a voluntary ombud scheme) and a market infrastructure. The decisions referred to in section 219 are defined in section 218. First, the Tribunal may reconsider a decision relating to a financial sector law, taken by either a financial sector regulator or the OC. The Tribunal may also review a decision taken by a statutory ombud (not a voluntary ombud) concerning a specific consumer complaint. This means that the $\mathrm{OC}$ is able to review the decision of a voluntary ombud scheme, but the FST may still review that OC decision. Then, the FST can directly investigate a decision made by either (1) an authorised financial services provider under the FAIS Act or (2) a decision

57 Van Zyl 200617 Stell LR 339-340.

58 FinMark Trust "Landscape for Consumer Recourse in South Africa's Financial Services Sector" (2007) http://www.finmark.org.za/documents/R_consumerrecourse.pdf (accessed 2020-04-21) 26 
contemplated under section 105 of the Financial Markets Act 59 made by a market infrastructure. The "decision" referred to in section 218 also includes certain omissions. The first type of omission relates to the period within which a provider must take a decision. It is an omission if the decision-maker has not made a decision either within the period prescribed or specified in a financial sector law, ${ }^{60}$ or, where there is no prescribed period, within a reasonable period.61 It is also an omission to avoid taking action, either within a specified period or, alternatively, within a reasonable period after making the decision. An FST order has the same force and effect as a civil judgment - that is, it is enforceable as if a court delivered the decision. ${ }^{62}$

\section{Influence of the FSR Act on the issues related to the previous regulatory structure}

The National Treasury policy document, "A Known and Trusted Ombud System for All", illustrates some issues associated with the current framework, which issues I mention and add to below. ${ }^{63}$ The first issue, the lack of consistency in the standards and/or requirements concerning dispute resolution processes, is resolved for the most part. The OC rules apply, and ombud schemes must incorporate the rules as part of their terms of reference. Previously, the FSOS Council prepared the standards for each ombud scheme; thus, the standard was arguably particular to an ombud scheme. Moreover, one body, namely the OC, will now be responsible for confirming whether an ombud scheme complies with financial sector laws. The OC must identify the best-practice standards to be implemented as part of the ombud scheme structure. Then, the OC needs to decide how to balance implementing standardised rules while also adopting a principlebased approach. Put in simple terms, the OC must decide to what extent each ombud has the option to deviate in its application of the prescribed fundamental principles mentioned above, which principles are included in the $\mathrm{OC}$ rules.

Another identified issue is the lack of clear and standardised guidelines against which to measure the performance of ombud schemes. ${ }^{64}$ This inconsistency will be resolved when the OC rules prescribe the standards and requirements that all ombud schemes should adopt. However, the content of the fundamental principles, the foundation of the OC rules namely, ensuring consumers have access to affordable, effective, independent and fair ADR processes - must be explained. An ombud scheme must comprehend the content of a fundamental principle to

\footnotetext{
19 of 2012.

$S 218(f)$ of the FSR Act.

$\mathrm{S} 218(\mathrm{~g})$ of the FSR Act.

S 236(2) of the FSR Act.

63 National Treasury http://www.treasury.gov.za/twinpeaks/Final\%20Twin\%20Peaks\%20 Policy\%20Doc_A\%20known\%20and\%20trusted\%20ombuds\%20system\%20for\%20all_Sep tember2017.pdf 8-15.

64 National Treasury http://www.treasury.gov.za/twinpeaks/Final\%20Twin\%20Peaks\%20 Policy\%20Doc_A\%20known\%20and\%20trusted\%20ombuds\%20system\%20for\%20all_Sep tember2017.pdf 15.
} 
determine whether it complies with the principle or not, and also to what extent the ombud may incorporate the principle in a manner that is uniquely suitable to its specific mandate.

The overlap in the jurisdiction of the OBS and FAIS Ombud remains an issue. Nevertheless, one of the OC's functions to issue standards that would reduce the overlap and then also decide which ombud scheme should have exclusive jurisdiction over a particular matter when there is an overlap. Practically, this issue will only be resolved when the OC operates as a single-entry point for consumer complaints. Nevertheless, if the OC delays deciding which ombud scheme has jurisdiction, this will result in a consumer experiencing the ombud scheme structure as ineffective.

An issue with the previous system is the lack of an effective referral process where a complaint goes to the incorrect ombud scheme. ${ }^{65}$ The OC rules should include a standard process applicable to all ombud schemes for complaint referrals. Also, one function of the $\mathrm{OC}$ is to improve the coordination between ombud schemes, which it is hoped will lead to creating a referral platform. Otherwise, the lack of an effective referral process compromises the confidence in the entire ombud scheme system when it is the customer's perception that the complaint takes too long to resolve, and even more so when a consumer is sent from pillar to post.

Another issue with the outgoing system is that each ombud scheme has used different standards for reporting, causing inconsistency in the level of transparency between schemes. The reporting method needs to be consistent between all ombud schemes. Also, the reporting duty should cause a sector regulator to detect systemic consumer abuse. It is not enough to have an annual reporting duty.

The previous structure creates no direct and binding duty, either on the FSOS Council or an ombud scheme to educate consumers. Two functions of the OC may resolve this issue - namely, improving the public awareness of ombud schemes and publicising information concerning ombud schemes. Arguably, the OC, by including an educational obligation in the OC rules, could delegate fulfilment of this function to ombud schemes. The FSCA will also have an education duty, which could include education on ombud schemes. This duty may be delegated to financial institutions through the FSCA conduct standards.

\section{INTERNAL COMPLAINT RESOLUTION MECHANISMS}

The discussion concerning internal complaint resolution mechanisms includes: (1) whether the existing regulatory instruments prescribe standards and/or requirements for an internal dispute resolution framework; (2) the extent to which the proposed regulatory framework will amend internal complaint resolution mechanisms; and (3) whether the measures forming

65 National Treasury http://www.treasury.gov.za/twinpeaks/Final\%20Twin\%20Peaks\%20 Policy\%20Doc_A\%20known\%20and\%20trusted\%20ombuds\%20system\%20for\%20all_Sep tember2017.pdf 11 . 
part of the proposed regulatory framework resolve the issues associated with the existing regulatory framework.

\section{Standards and/or requirements under the existing framework}

Complaint forums operating in the banking sector require consumers first to attempt to resolve a dispute directly with their bank. ${ }^{66}$ The assumption is that all banks prepare a written Customer Management Framework (CMF). Before the promulgation of the FSR Act, industry codes influenced the requirements for a CMF. The Banking Code prescribes, among other things, general standards that banks must incorporate as part of the internal dispute resolution process. Nevertheless, key principles forming the foundation for the Banking Code - namely, fairness, transparency, accountability and reliability - apply equally to the part of the Code concerning consumer complaints. Part 10 of the Banking Code provides an introductory discussion of the expectation from a bank during an internal dispute resolution process. The general standards provide that call centre staff will assist with queries and provide time frames for when a bank must take a specific action. A bank must acknowledge receipt of a complaint within three business days, inform the customer of the status of the investigation of a complaint within 14 days, and also at this time give an estimated time by which it will resolve a complaint. The Banking Code prescribes no time limit to resolve a complaint. The second segment of part 10 informs a customer of the customer's right to approach the OBS when the bank fails to resolve a complaint. ${ }^{67}$

The Financial Services Providers Code provisions concerning the internal complaint resolution system and procedures are more detailed than those of the Banking Code. According to the Financial Services Providers Code, the internal complaint resolution relies on the following principles: (1) the provider must have a comprehensive complaints policy emphasising the provider's commitment to the complaint process, and also explaining the system and procedures associated with complaint resolution; (2) the internal complaint resolution system and procedures must be transparent and visible; (3) clients must have access at any time of the day to the facilities to lodge a complaint; 68 and (4) there must be fairness in the resolution of the complaint. ${ }^{69}$ Moreover, paragraph 19 of the Code imposes specific obligations on the provider when it comes to internal complaint resolution. First, the details of the internal complaint resolution system and procedures and any amendments thereto should be in writing. In addition, the details and contact particulars of the FAIS Ombud must be communicated to clients. Moreover, the customer must submit a written complaint accompanied by all the relevant information and copies of relevant documents. Then, the provider must "promptly" acknowledge receipt of a

66 See the mandate of the FAIS Ombud https://faisombud.co.za/about-us/mandate/ (accessed 2020-04-28).

67 See the Banking Code 35-36.

68 FAIS Code par 17(c) and 19(1)(ii).

69 FAIS Code par 17. 
complaint in writing, but there is no clear guideline on what constitutes "promptly". With regard to the outcome of the complaint, the client must be informed within six weeks where the provider is unable to resolve a complaint according to the FAIS Ombud Rules. Also, where the outcome is not favourable to the client, the provider must provide written reasons for the complaint outcome while also indicating that the client may pursue the matter further with the FAIS Ombud within six months.

\section{Standards and/or requirements under the proposed framework}

The FSR Act imposed additional standards and endowed the relevant regulator with authority to issue additional standards, which, among other things, will inform how banks must manage the internal dispute resolution process. The FSCA will be responsible for evaluating the internal dispute resolution mechanisms of financial institutions. It is one of the objectives of the FSCA to protect financial customers, first by promoting the fair treatment of financial customers by financial institutions, and also through educating financial customers on issues concerning financial literacy. ${ }^{70}$ This function would arguably also include ensuring the protection of financial customers that results from access to effective internal and external complaint mechanisms. According to section 106 of the FSR Act, the FSCA may issue conduct standards for financial institutions to achieve specific objectives. ${ }^{71}$ In terms of section 106(3)(c)(iii), the FSCA may issue a conduct standard aimed to achieve fair treatment of financial customers. Accordingly, an FSCA conduct standard may prescribe requirements for the internal complaint resolutions mechanisms of banks as a financial institution. Additionally, the FSCA can request ombud schemes to report on aspects of complaint resolution. The purpose of this reporting duty is arguably to identify systemic infringement of consumer rights so that the FSCA may implement an industry-wide intervention to issue standards concerning the internal complaint mechanisms.

The COFI Bill will prescribe how financial institutions (including banks) should treat their clients, in line with the TCF principles. More specifically, TCF principle 6, which provides that a customer should "not face unreasonable post-sale barriers imposed by firms to change product, switch providers, submit a claim or make a complaint", applies to the resolution of consumer complaints. ${ }^{72}$ The COFI Bill intends to follow a principle-based approach and will establish binding principles that must be adhered to by the role players in the financial sector. ${ }^{73}$ Chapter 7 , consisting of sections 32 to 35 , relates to dealing with the post-sale barriers faced by financial

$S 57(b)$ of the FSR Act.

S 67 of the COFI Bill relates to conduct standards the FSCA may issue. Any reference to a section of the COFI Bill refers to the section in the second draft of the Bill.

72 FSB https://www.fsca.co.za/Regulatory\%20Frameworks/Documents\%20for\%20 Consultation/TCF\%20Complaints\%20Management\%20Discussion\%20Document.pdf 1 .

73 National Treasury http://pmg-assets.s3-website-eu-west1.amazonaws.com/181211CoFI_ Bill_policy_paper.pdf 14 . 
customers, and the obligations of financial institutions in this regard. A Chapter 7 purpose concerns the fair treatment of financial customers after they conclude a contract for "a financial product, financial instrument or financial service". Accordingly, complaint resolution mechanisms contribute to whether or not there is fair treatment of financial customers. Section 33 relates directly to complaints management. In terms of section $33(1)(d)$, a financial institution must not impose post-sale barriers that will prevent a financial customer from lodging a complaint. Section 33(2)(c) involves providing financial customers "with efficient and effective complaints management" where a complaint may be resolved "in a fair and expeditious manner". Then, section 33(2)(d) requires that a financial institution monitor complaints. Moreover, a financial customer should be advised about, and have access to not only an effective internal complaint mechanism but also an external dispute resolution mechanism according to section 33(2)(f).

\section{Influence of the FSR Act and the COFI Bill on the issues related to the previous regulatory structure}

The Banking Code and the Financial Services Providers Code impose those obligations that are placed on banks to develop and then implement internal complaint mechanisms. Nevertheless, there is no direct statutory obligation on a bank to establish an internal complaint mechanism that complies with specific standards. The FSR Act provides the FSCA with authority to issue conduct standards to achieve the fair treatment of financial customers, and more specifically, standards concerning complaint resolution. ${ }^{74}$ Therefore, all banks (as financial institutions) would have to follow the provisions of these conduct standards. Accordingly, in July 2020, the FSCA issued Conduct Standard 3 of 2020 (Banks), referred to as the Conduct Standard for Banks. Section 8 of the Conduct Standard for Banks is very prescriptive on the requirements that must be included as part of a bank's complaints management framework. ${ }^{75}$

The Banking Code does not place a direct obligation on a bank to educate clients on the availability of an internal complaint resolution mechanism. The Code merely states that a bank should inform a client how to lodge a complaint and where to go if unsatisfied with the outcome. The FAIS Code refers to transparency and visibility as essential principles that should form part of an internal complaint resolution mechanism. Implementation of these fundamental principles requires that a financial services provider must have full knowledge of internal complaint resolution procedures, which implies an obligation to educate a consumer. Section 33(2)(f) of the COFI Bill imposes a statutory educational obligation on a financial institution, where the institution should not only provide access to an effective internal complaint mechanism but also inform customers on the availability of this forum. Accordingly, the obligation to provide education that an internal complaint mechanism is available to a financial customer will become a statutory

74 S 106(3)(c)(iii) of the FSR Act.

75 A detailed analysis of the Conduct Standard for Banks forms part of future research. 
obligation. However, the extent of this duty is left open to interpretation. It may end up being a "tick-box exercise" where the financial institutions comply with the letter of the provision without considering the purpose behind the obligation.

At present, none of the codes includes an obligation that a bank should keep records of complaints it has received. Moreover, banks have no obligation to report to a regulator concerning the implementation and outcome of their internal complaint mechanisms. Section 55 of the COFI Bill places a general obligation on a financial institution to implement a framework to retain data and records, which general provision would also apply to complaints it has received. However, this section is too general to impose a specific duty on a financial institution concerning the complaints a financial institution receives.

\section{CONCLUDING REMARKS}

This contribution highlights the changes from the old to the new regulatory framework and identifies which aspects of the amended regulatory framework should address a specific issue associated with the outgoing dispute resolution framework. It is not argued whether this legislation will achieve the fair treatment and protection of financial customers in the banking sector, as only time will tell. However, it is acknowledged that the revised structure will improve the consistency and efficacy of the dispute resolution structure in the banking sector, especially with the introduction of one regulatory authority, the OC, for statutory and voluntary ombud schemes. To introduce a principle-based approach will allow the appropriate level of flexibility, but still promote consistency between the ombud schemes and also among banks. However, it will not help if these fundamental principles become a "catch-all" phrase. Therefore, there should be a clear interpretation of what these principles entail, and content analysis should form part of future research.

All indications are that the previous structure will remain, albeit that a single body, the OC, will carry the oversight function. It does appear that much of whether the new external dispute resolution structure will be effective is going to depend on how well the OC rules are drafted. Also, the FSR Act provides the FSCA with authority to prepare conduct standards concerning complaint resolution. These conduct standards should result in a consistent approach among financial institutions when dealing with customer complaints. However, as with the $\mathrm{OC}$ rules, whether the internal complaint mechanism of banks functions effectively will depend on how well these conduct standards are drafted. At least, the legally binding nature of the OC rules and FSCA conduct standards will be stronger than an industry code. 